\title{
Construction of the Belt and Road Initiative in Chinese and American Media: A Critical Discourse Analysis Based on Self-Built Corpora
}

\author{
Ya Xiao ${ }^{1}, \mathrm{Yue}^{1}{ }^{1} \& \mathrm{Jie} \mathrm{Hu}^{1}$ \\ ${ }^{1}$ Department of Linguistics and Translation, School of Linguistics and Translation, Zhejiang University, \\ Hangzhou, China \\ Ya Xiao and Yue Li contribute equally to this article. \\ Correspondence: Jie Hu, Department of Linguistics and Translation, School of International Studies, Zhejiang \\ University, Hangzhou, 310058, China. ORCID: http://orcid.org/0000-0003-2219-2587. E-mail: huj@zju.edu.cn
}

Received: March 2, 2019 Accepted: March 26, 2019 Online Published: April 6, 2019

doi:10.5539/ijel.v9n3p68 URL: https://doi.org/10.5539/ijel.v9n3p68

\begin{abstract}
The Belt and Road Initiative reflects China's ascendance in the world arena. Since its inception, this initiative has received great attention from Chinese and American media. This study applies the critical discourse analysis (CDA) method to investigate the mainstream media construction of the Belt and Road Initiative. Based on the "Lexis Advance" database, a sample of news reports dated between January, 2017 and November, 2018 were selected to build two corpora of China Daily (368 reports with 232550 words) and The New York Times (154 reports with 106401 words). Assisted by the two self-built corpora and the corpus software AntConc 3.2.4, the study probes into the similarities and differences between Chinese and American reports in terms of high-frequency words, collocation networks, concordance lines and concordance plots. The findings are (1) both the Chinese and American media pay great attention to the contribution of this initiative to the world economy. (2) Chinese media emphasize the concrete measures of this initiative, while American media focus on its political influence. (3) Chinese media use explicit positive vocabulary to appraise the achievement of this initiative, while American media use explicit negative vocabulary to express Trump administration's skepticism about this initiative. (4) American government's attitudes towards this initiative have gradually changed since Trump came to power. Though negative comments still exist, the positive voice has increased.
\end{abstract}

Keywords: Belt and Road Initiative, China Daily, corpus-based tool, critical discourse analysis, meaning construction, The New York Times

\section{Introduction}

In September and October of 2013, Chinese President Xi Jinping raised the initiative of building the "Silk Road Economic Belt" and the "21st Century Maritime Silk Road" in his speeches delivered in Kazakhstan and Indonesia, marking the beginning of the "Belt and Road Initiative". Borrowing the historical symbol of the ancient Silk Road, the initiative aims to promote infrastructure development of the countries along the Belt and Road and contribute to regional economic cooperation. Since the introduction, its circle of friends has become larger and larger, drawing sustained attention and mixed reactions from domestic and foreign media. Several foreign media in their reports have deciphered the motives behind the initiative and speculated on its future direction and geopolitical influence.

In China, researches on the Belt and Road Initiative are on the rise, mainly focusing on the underlying philosophy, cultural dissemination and international cooperation against the background of this initiative. As for the underlying philosophy, researchers state that the idea of building a community of shared future for mankind put forward by the initiative contains the traditional Daoist philosophy of "the unity of heaven and man" (Muhammad \& Ling, 2018) and the ethical values of Confucianism, i.e., justice, harmony and benevolence ( $\mathrm{Li}$, 2015). In terms of cultural dissemination, most studies explore the going-out strategy of Chinese culture (e.g., Hao, Lu, \& Guy, 2018; Yang et al., 2017) and Chinese language (Chen \& Hu, 2018; Hu \& Wei, 2018; Yan, 2018). For instance, Hao, Lu and Guy (2018) conduct a quantitative analysis on the cultural distances in genre preference between China and other countries involved in the Belt and Road Initiative based on 2016 box office data. Meanwhile, as for traditional Chinese culture, Yang et al. (2017, p. 343) investigate the spreading of acupuncture in countries along the Belt and Road, claiming that this initiative could enhance "China's soft 
strength" and further create a "fine cultural environment for the economic prosperity". Concerning the Chinese language, $\mathrm{Hu}$ and Wei $(2018$, p. 2) stress the desirability of creativity in language teaching against the background of the Belt and Road Initiative since it is an "elusive concept that lies at the center of education". Also, Yan (2018, p. 496) sheds light on the spreading of Chinese as a second language, and the maintenance of Chinese minorities under the "ecology-of-language paradigm", which reflects an inclusive notion of "coexistence of variety, harmony in diversity" in this initiative. In addition, researchers attempt to probe into the international cooperation in the areas of foreign direct investment (Du \& Zhang, 2018), manufacturing industries (Hou, Chen, \& Xiao, 2018), energy efficiency and saving (Han et al., 2018; Zhang, Jin, \& Shen, 2018), space exploration $(\mathrm{Li}, 2015)$ and other issues related to the "Belt and Road Initiative" through field interviews and questionnaires.

Foreign researchers also conduct studies of the "Belt and Road Initiative", mostly in the field of geopolitics. This initiative is considered as China's ongoing geopolitical strategy that links Eurasia to promote East-West economic cooperation through trade and energy projects in Central Asia. Its possibility of merging with Russia's geopolitical strategy will have an impact on the economic situation in the European Union (Blanchard \& Flint, 2017; Zhao, 2016). The Belt and Road Initiative and Asian Infrastructure Investment Bank take advantage of China's strengths in infrastructure development, financial clout and manufacturing, both of which bring capital injections to countries along the Belt and Road and provide channels for Chinese companies to invest abroad. Ties between China and other Asian countries are thus strengthened, making China a geopolitical and economic hub for the Asian region (Hong, 2016; Summers, 2016).

Previous studies mentioned above show that in recent years, the Belt and Road Initiative has attracted scholars' growing attention and valuable contributions have been made, which provide theoretical support for this study. However, predecessors' studies are mostly empirical, focusing on the economic, political and cultural influence of the Belt and Road Initiative. This initiative is rarely analyzed from the perspective of critical discourse analysis, leaving plenty of room for comparative studies based on the corpus.

Thus, to supplement the existing researches, this study builds a corpus of Chinese and American media reports of the Belt and Road Initiative and conducts a qualitative and quantitative analysis of the data to find out the differences in discourse construction, and attitudinal changes between China and America, and to explore the underlying political intentions. In particular, this study aims to answer these two questions (1) What are the similarities and differences between Chinese and American corpora in terms of high-frequency words, collocation networks, concordance lines and concordance plots? (2) What are the underlying reasons for the similarities and differences from the perspective of the social-cultural context? The findings are expected to provide constructive suggestions for the external dissemination of this initiative and enhance China's international voice.

\section{Method and Materials}

In the late 1980s, Fairclough (1995) proposed the theory of critical discourse analysis (CDA in short thereafter), which studies the language interaction in a real social environment. Discourse is a kind of social phenomenon that is restricted by social conditions. As discourse hides opaque power relations in modern society, the CDA aims to make these relationships more apparent (Northey \& Mckibbin, 1999). Focusing on the power and ideology projected by discourse objects and communicative patterns, the CDA tries to explain the relationship between discourse and social structure (Fairclough, 1992; Wei, Yang, Chen, \& Hu, 2018).

However, the traditional CDA is always used to analyze the limited materials qualitatively. Its weak interpretation ability is criticized for the subjective selection of corpus and the lack of data-supported analysis results. Baker et al. (2008) first combined the CDA with the data-based approach and then continuously perfected the research framework of CDA on the basis of the corpus. The combination of quantitative and qualitative analyses can greatly avoid the subjective intervention of researchers in the corpus. Thus, more authoritative and objective analysis results are provided, which is of milestone significance.

By limiting five key terms in the "Lexis Advance" database, namely, "Belt and Road Initiative", "One Belt One Road", "maritime silk road", "new silk road" and "silk road economic belt", this study respectively extracted news highly relevant to the Belt and Road Initiative from China Daily and The New York Times, all of which are reported from the January 20th, 2017 when the Trump administration came to power to the November 1st, 2018 when the data analysis began. The "Lexis Advance" database contains many world-renowned journals and magazines, providing a wide range of information in full text and are updated instantly. China Daily and The New York Times included in the database are the mainstream media in China and America, which to a certain extent, ensures the integrity, authority and authenticity of this study. In the two self-built corpora, the number of 
Chinese reports reached 368 with a total of 232550 words while the number of American reports was 154, with 106401 words in total. AntConc 3.2.4 and the CDA were employed in this study to conduct a comparative analysis of the data in Chinese and American corpora in terms of high-frequency words, collocation networks, concordance lines and concordance plots.

\section{Data Analysis and Results}

\subsection{High-Frequency Word Analysis}

Word frequency statistics is a basic means used in corpus researches. To examine the semantic representation of discourse, high-frequency words were first analyzed in Chinese and American data respectively. Despite the high frequency of function words, they have no practical meaning as they only express grammatical meanings and serve to link different parts together. Since this study focuses on semantic research, "stop list" function in AntConc 3.2.4 was used to exclude function words and only the top 25 notional high-frequency words were discussed in detail, as shown in Table 1.

Table 1. Top 25 notional high-frequency words in Chinese and American corpora

\begin{tabular}{lllll}
\hline & China Daily & & \multicolumn{2}{l}{ The New York Times } \\
\hline Rank & Freq. & Word & Freq. & Word \\
\hline 1 & 3172 & China & 1564 & China \\
2 & 1858 & Road & 810 & Chinese \\
3 & 1371 & Belt & 371 & Xi \\
4 & 1146 & countries & 355 & United \\
5 & 1109 & Chinese & 347 & Trump \\
6 & 956 & development & 316 & States \\
7 & 881 & cooperation & 299 & Beijing \\
8 & 789 & Initiative & 219 & new \\
9 & 769 & trade & 213 & world \\
10 & 696 & new & 198 & American \\
11 & 686 & Silk & 198 & countries \\
12 & 648 & world & 195 & government \\
13 & 630 & economic & 188 & economic \\
14 & 621 & people & 187 & power \\
15 & 570 & international & 185 & trade \\
16 & 537 & Xi & 171 & Road \\
17 & 515 & global & 155 & Korea \\
18 & 396 & Asia & 153 & Belt \\
19 & 369 & infrastructure & 147 & global \\
20 & 352 & investment & 143 & companies \\
21 & 329 & growth & 128 & projects \\
22 & 314 & companies & 126 & Asia \\
23 & 311 & Europe & 120 & India \\
24 & 304 & President & 120 & Pakistan \\
25 & 298 & projects & 117 & Europe \\
\hline & & & &
\end{tabular}

Table 1 shows that the top 25 notional high-frequency words in Chinese and American corpora largely reflect the main contents of news reports on the Belt and Road Initiative in these two countries. China Daily and The New York Times share 14 high-frequency words, namely, "China", "Road", "Belt", "countries", "Chinese", "Initiative", "trade", "new", "world", "economic", "Xi”, "global”, "Asia", "Europe" and "projects". Words like "development", "cooperation", "initiative", "Silk", "People", "international", "infrastructure", "investment", "growth", "companies" and "President" were unique to the Chinese data while words including "United", "Trump", "States", "Beijing", "American", "government", "power", "Korea", "Companies", "India" and "Pakistan" only appeared in the American reports. It reflects that Chinese and American media differ in their focuses when reporting this initiative. The high-frequency words that appeared merely in China Daily were mostly related to the economic development and the infrastructure construction, which might be due to the fact that Chinese media emphasized the specific measures and the promising future of the Belt and Road Initiative. On the other hand, the words of high frequency in The New York Times were closely associated with the international relationships, the possible explanation of which could be that the American media underlined the possible changes this initiative might bring to the global political pattern. 


\subsection{Collocation Network Analysis}

To further analyze the main content of the initiative and find out the differences between Chinese and American reports, collocation networks of high-frequency words were constructed with the help of the "cluster" function in AntConc 3.2.4, in which "China" was used as the central node word and ten words most frequently collocated with "China" were seen as the first-level nodes. The following two collocation networks more intuitively showed the connection between high-frequency words, which made it easier to explore two countries' distinctive attitudes towards the Belt and Road Initiative.

From the collocation network of high-frequency words in the Chinese corpus, it could be found that the first-level nodes were "South", "railway", "US", "Pakistan", "new", "ASEAN", "western", "sea", "east" and "Europe" and each first-level node was connected to multiple second-level nodes (see Figure 1).

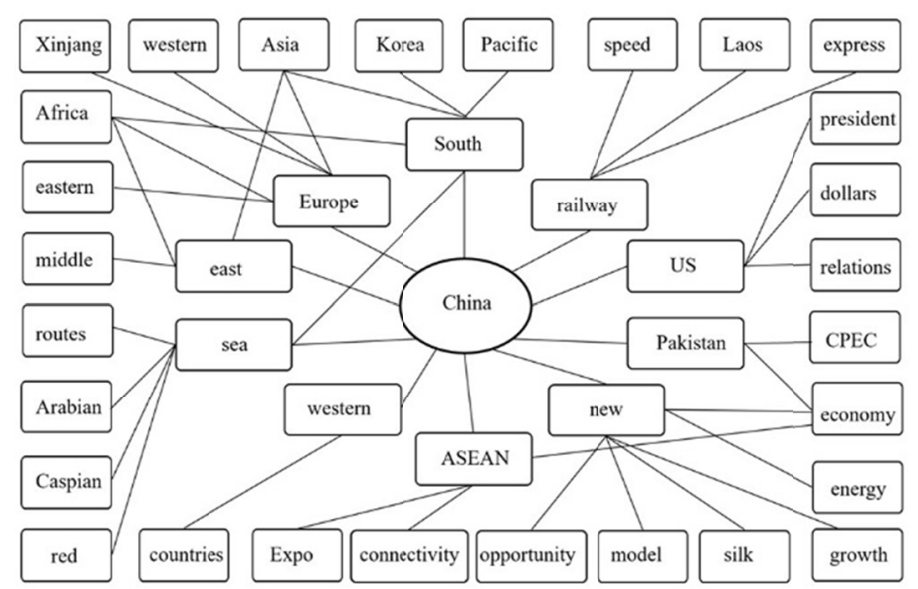

Figure 1. Collocation network of high-frequency words in the Chinese corpus

Note. ASEAN refers to the Association of Southeast Asian Nations.

The collocation network of high-frequency words in the American corpus showed that "rising", "Pakistan" "sea", "central", "Europe", "South", "relations", "counter", "market", and "control" were ten first-level nodes, each of which was collocated with several second-level nodes (see Figure 2).

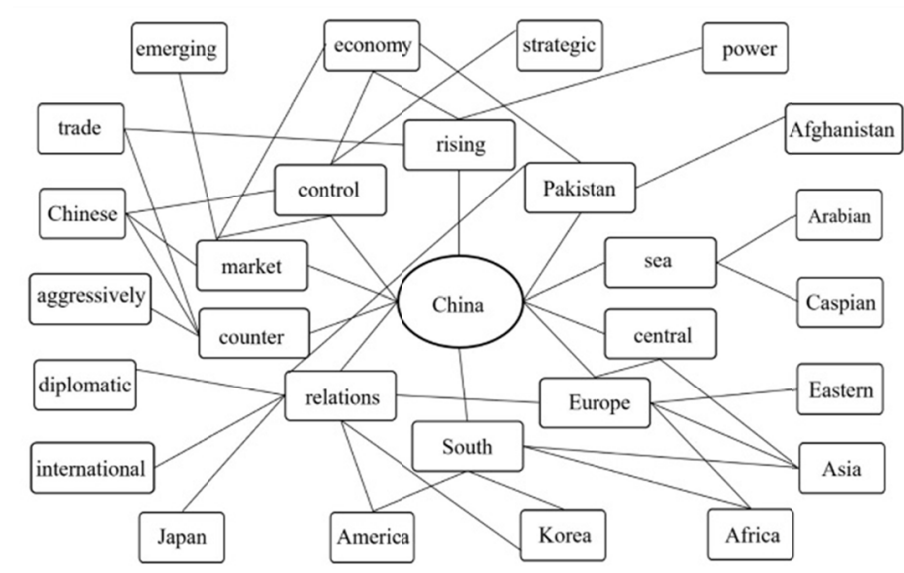

Figure 2. Collocation network of high-frequency words in the American corpus

\subsection{Concordance Line Analysis}

To reveal the attitudes of Chinese and American media towards the initiative thoroughly, the concordance line analysis was conducted. The co-text of the key term "Belt and Road Initiative" could be seen in Table 2. 
Table 2. Concordance lines of the Belt and Road Initiative in Chinese and American corpora

\begin{tabular}{|c|c|c|c|}
\hline \multicolumn{4}{|c|}{ China Daily } \\
\hline 1 & $\begin{array}{l}\text { Different from the Marshall Plan to rebuild } \\
\text { war-torn European States }\end{array}$ & Belt and Road Initiative & $\begin{array}{l}\text { is inclusive and invites all countries to } \\
\text { participate. }\end{array}$ \\
\hline 2 & $\mathrm{Xi}$ made his ambitions for the & Belt and Road Initiative & $\begin{array}{l}\text { clear at the World Economic Forum in Davos, } \\
\text { Switzerland, in January, when he defended } \\
\text { globalization and called for countries to } \\
\text { work together to tackle uncertainties. }\end{array}$ \\
\hline 3 & $\begin{array}{l}\text { However, the most ambitious and } \\
\text { promising institutional initiative in this } \\
\text { context is by far the }\end{array}$ & Belt and Road Initiative & 1 \\
\hline 4 & Small wonder that the China-proposed & Belt and Road Initiative & $\begin{array}{l}\text { a massive economic and trade project for } \\
\text { common development and prosperity in } \\
\text { countries along its routes in Europe, Africa } \\
\text { and Asia }\end{array}$ \\
\hline 5 & $\begin{array}{l}\text { Japan was willing to participate in the } \\
\text { China-proposed }\end{array}$ & Belt and Road Initiative & $\begin{array}{l}\text { that is aimed at improving connectivity } \\
\text { between Asia and the Middle East, Europe } \\
\text { and Africa. }\end{array}$ \\
\hline 6 & The China-proposed & Belt and Road Initiative & $\begin{array}{l}\text { is a key program to increase connectivity } \\
\text { within the region }\end{array}$ \\
\hline 7 & $\begin{array}{l}\text { we will open up wider and at higher levels by } \\
\text { building around the }\end{array}$ & Belt and Road Initiative & $\begin{array}{l}\text { to pursue win-win and all-win results with } \\
\text { the world. }\end{array}$ \\
\hline 8 & $\begin{array}{l}\text { Huawei's efforts to boost sustainable } \\
\text { development in Africa finds its roots in }\end{array}$ & Belt and Road Initiative & $\begin{array}{l}\text { which pursues global cooperation by } \\
\text { building or improving infrastructure. }\end{array}$ \\
\hline \multicolumn{4}{|c|}{ The New York Times } \\
\hline 1 & The & $\begin{array}{l}\text { "One Belt, One Road" } \\
\text { initiative }\end{array}$ & $\begin{array}{l}\text { would dwarf the United States' post-World } \\
\text { War II Marshall Plan }\end{array}$ \\
\hline 2 & $\begin{array}{l}\text { China marches on with its unabashedly } \\
\text { ambitious global-expansion program known } \\
\text { as }\end{array}$ & $\begin{array}{l}\text { "One Belt, One Road" } \\
\text { initiative }\end{array}$ & 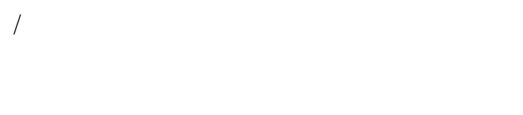 \\
\hline 3 & As part of Beijing's ambitious & $\begin{array}{l}\text { "One Belt, One Road" } \\
\text { initiative }\end{array}$ & $\begin{array}{l}\text { it is designed to expand Chinese global } \\
\text { influence. }\end{array}$ \\
\hline 4 & China's & $\begin{array}{l}\text { "One Belt, One Road" } \\
\text { initiative }\end{array}$ & $\begin{array}{l}\text { an economic expansion plan, is overly } \\
\text { ambitious because it is aspirational. }\end{array}$ \\
\hline 5 & The & $\begin{array}{l}\text { "One Belt, One Road" } \\
\text { initiative }\end{array}$ & $\begin{array}{l}\text { led by China, would expand the country's } \\
\text { influence. }\end{array}$ \\
\hline 6 & $\begin{array}{l}\mathrm{Xi} \text { will struggle to persuade skeptical } \\
\text { countries that the }\end{array}$ & $\begin{array}{l}\text { "One Belt, One Road" } \\
\text { initiative }\end{array}$ & is not a smokescreen for strategic control. \\
\hline 7 & $\begin{array}{l}\text { China has also begun pulling small countries } \\
\text { on its periphery into its orbit through a lavish } \\
\text { infrastructure plan called the }\end{array}$ & $\begin{array}{l}\text { "One Belt, One Road" } \\
\text { initiative }\end{array}$ & / \\
\hline 8 & Through the & $\begin{array}{l}\text { "One Belt, One Road" } \\
\text { initiative }\end{array}$ & $\begin{array}{l}\text { China is ready to extend its dominance over } \\
\text { the North's small and decrepit economy, } \\
\text { where signs of an emerging market economy } \\
\text { are also strengthening China's hand. }\end{array}$ \\
\hline
\end{tabular}

Note. Words that deserve particular-attention in the concordance lines were shown in boldface because these words intuitively reflected different attitudes of the American and Chinese media in the coverage. Detailed interpretations of the political intentions embodied in these attitudinal attitudes were illustrated in 4.3 below.

\subsection{Concordance Plot Analysis}

As the world's largest economy, America plays a pivotal role on the world stage. How the United States views China's Belt and Road Initiative will inevitably affect the corresponding decisions of other countries. Therefore, tracking the changes in America's perceptions of and attitudes towards the Belt and Road Initiative is of particular-significance in terms of academia and practices.

In this regard, this study sorted the corpus by time and used the "concordance plot" function to draw the distribution of attitudinal words to visualize their trends and further interpret the change of the American media's attitudes (see Table 3). 
Table 3. List of the concordance plots of words related to American media's attitudes.

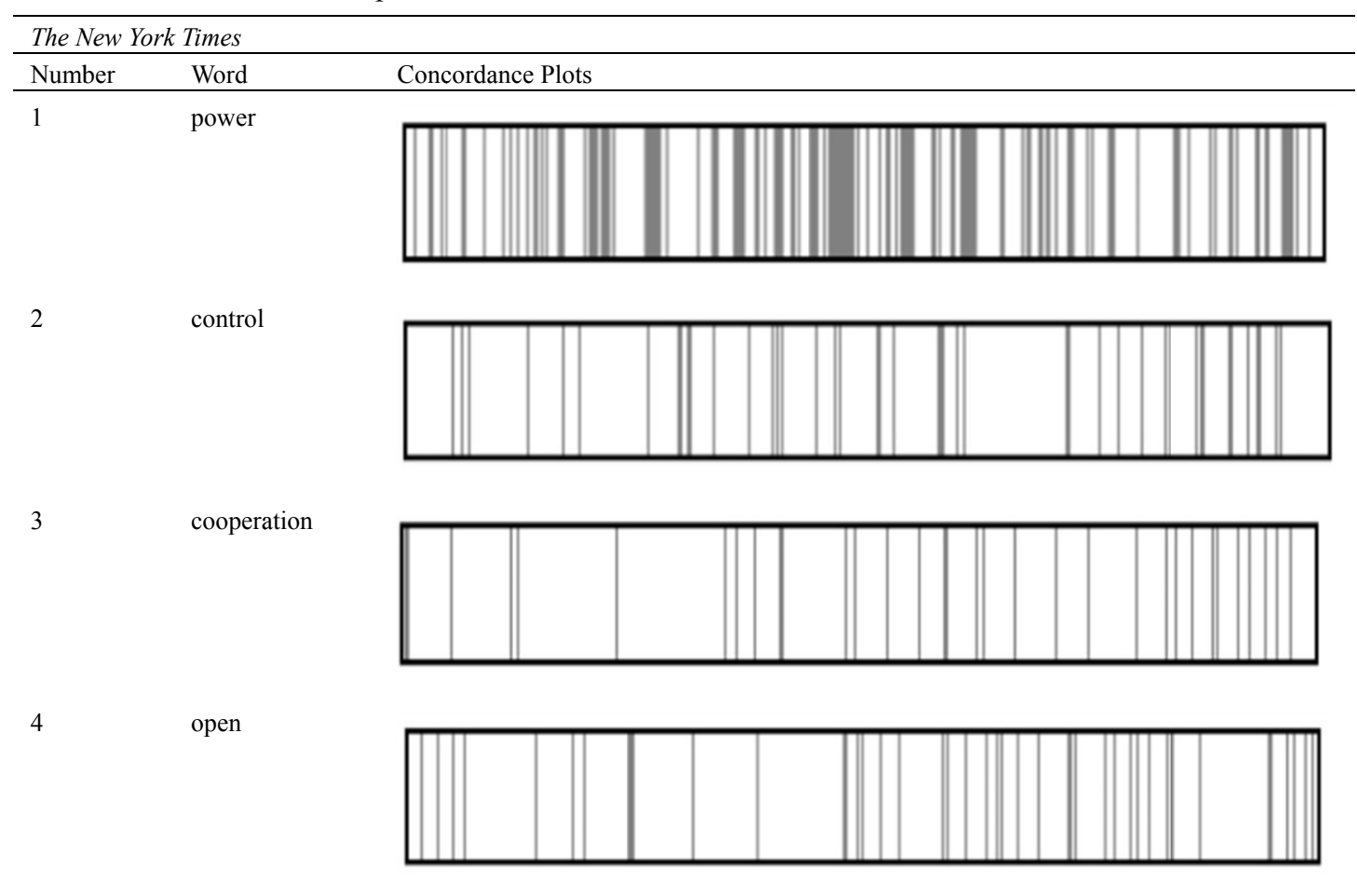

\section{Discussion}

\subsection{High-Frequency Words}

The 15-overlapping high-frequency words (China, road, belt, countries, Chinese, Initiative, trade, new, world, economic, Xi, global, Asia, Europe, projects) reflect the consensus of the two countries on the initiative. Specifically, both Chinese and American media emphasize the significant role that China has played in this initiative because "China" ranks the first in the relevant reports of both China Daily and The New York Times. In the meanwhile, the name of President Xi Jinping has also been mentioned many times since he is the leading figure in proposing and implementing this initiative. As for the distinguishable characteristics of the Belt and Road Initiative, the innovation of this initiative is agreed upon, which can be seen from the high frequency of "new". Additionally, "economic" and "trade" reflect that the Belt and Road Initiative has injected vitality into economic development. Meanwhile, "countries", "world" and "global" display the international vision of the initiative. In detail, this initiative covers more than 68 countries, aiming to actively build a new type of relationship among the major powers and promote the construction of a community of common destiny in the context of globalization. As most of the participating countries in Asia-Pacific region are developing countries or economies in transition, this initiative provides an excellent opportunity for accelerating the economic cooperation among these countries and promoting the overall prosperity in the Asia-Pacific region. At the same time, as China's biggest business partners, the economic strength of the Western European economic circle cannot be neglected. Therefore, "Asia" and "Europe" are also high-frequency words reported by the media in both countries.

The unique high-frequency words in the Chinese and American corpus respectively reflect on the differences in the focus of reports from the media of the two sides. In particular, the Chinese side emphasizes the basic content of the Belt and Road Initiative and its international strategic significance. As one of the largest projects on "infrastructures" and "investment" in history, this initiative promotes economic, political and cultural "cooperation" among various countries, for the benefit of the "people" of the world. While the American side puts more focus on the political influence of China's Belt and Road Initiative since "government" is a high-frequency word. To be more specific, the Trump government is sensitive to the potential threat this initiative might bring to America. For instance, "India" and "Pakistan" have been mentioned many times in the reports of The New York Times. It is due to that the China-Pakistan Economic Corridor built under the Belt and Road Initiative passes through Kashmir, which has caused India's misunderstanding. The implementation of an initiative will inevitably face various challenges. But the American media concentrate the coverage on the 
controversy in the implementation process to render a tense atmosphere. In addition, "power" shows up as a unique high-frequency word in the reports of the American media, which reflect America's concern about the increasingly powerful China.

\subsection{Collocation Networks of the High-Frequency Words}

Judging from the Chinese corpus, this initiative has entered the stage of pragmatic cooperation between China and countries along the Belt and Road. As shown, "ASEAN" is the first-level node and "expo" is one of its second nodes. The reason might be that the Belt and Road Initiative gives priority to the Association of Southeast Asian Nations (ASEAN) in its implementation; the 15th ASEAN Expo held in Nanning, Guangxi from September 12th to 15th in 2018 took the theme of "Building the 21st Century Maritime Silk Road, Creating the China-ASEAN Community of Innovation". The successful construction of the China-ASEAN community of common destiny, which experiences the ups and downs, and shares weal or woe, is directly linked to the realization of the overall goal of the Belt and Road Initiative. Meanwhile, the benefits in terms of "connectivity" and "economics" for ASEAN brought by the Belt and Road Initiative have been repeatedly emphasized in relevant reports. As for another first-level node, i.e., "railway", it reflects the fact that China's news reports attach great importance to the infrastructure connectivity of the Belt and Road Initiative. A successful example of the infrastructure construction in this initiative is the China-Laos high-speed rail project, which has greatly improved the speed of local logistics and helped export goods. Therefore, "Laos" is a second-level node connected with the "railway". In terms of international relations, China and Pakistan have established an all-weather strategic partnership. The "China-Pakistan Economic Corridor (CPEC)" in the Belt and Road Initiative has further strengthened China-Pakistan cooperation and provided important opportunities. As the model project of the initiative, it is not surprising that "Pakistan" and the "CPEC" are the focus of China Daily. In addition, the influence of the Belt and Road Initiative in the "United States" (US) and "Europe" has also attracted the attention of the Chinese media. On the whole, the Chinese media is full of hope for the new development "model" and "opportunity" brought about by this initiative.

According to the American corpus, the international influence of the Belt and Road Initiative is laid great emphasis in The New York Times. The first-level nodes "market", "emerging" and "economy" in Figure 2 illustrate that the American side agrees that this initiative is related to economic cooperation and the emerging markets. However, compared with the economic benefits, the American media pay more attention to the political field, as what has been found from the high-frequency words. America believes that this initiative has a "diplomatic" significance, which will prompt China to establish closer "relations" with countries along the Belt and Road. Particularly, the relationships between China and "Pakistan", between China and "Europe" are at first underlined in the reports of American media. One possible explanation behind the two collocations is the benchmarking influence of the China-Pakistan Economic Corridor and the China-EU railway project. In addition, the first-level nodes "counter", "control" and "rising" are respectively connected with the second-level nodes "aggressively", "strategic" and "power", which reflects the concern of America. America believes that the main purpose of China's Belt and Road Initiative is to gradually enhance the status of China in the international community so as to compete with America through this initiative. The first-level nodes "south" and "sea" in the collocation network further testify the concern of America. To be specific, the Sino-American dispute over the South China Sea has been in existence for a long time. The international community's position on the South China Sea arbitration is not yet clear. The American side is worried that China's Belt and Road Initiative will affect the current situation, causing America to be in a disadvantaged position in this game. On the whole, the attitudes of American media to the Belt and Road Initiative is complex.

The comparison shows that the media of both countries mentioned the relationship between China and America, South Korea, Pakistan and Europe under the Belt and Road Initiative, but the emphasis of the reports is obviously different. The Chinese media pay more attention to the description of specific details, especially in terms of infrastructure construction and economic development. Thus, the coverage is richer. On the other hand, the reports of the American media appear to be general and superficial, emphasizing China's growing national power and rising international status. Therefore, the coverage is relatively simple. This finding is consistent with previous studies (Peter, 2016).

\subsection{Concordance Line Index}

At first, the American media compare the Belt and Road Initiative to the "Marshall plan" which aggravated the ideological opposition during the Cold War. The Chinese media clearly refute this statement and point out that there is a fundamental difference between the two; the Belt and Road Initiative is an "inclusive" program that "invites all countries" to participate, which converges with previous findings (Liu, Tian, \& Liu, 2018). Also, the 
word "ambition" appears in the reports from both sides, but apparently expresses different emotions. Specifically, the American media believe that China's intention of proposing this initiative is to "expand its global influence", while the Chinese media clearly state that the initiative aims to better "defend globalization" and seek peaceful development, thus is "promising". In the meanwhile, the attributive word of the Belt and Road Initiative in the American media's coverage is mostly "China-led", which reflects America's uneasiness towards China's leading position in this initiative; while the Chinese media mostly use "China-proposed", indicating that the initiative is raised by China, but the opportunity belongs to the world. In addition, Chinese media use explicit positive vocabulary, such as "pursue", "improve", "build", "raise" and "increase", to affirm the significance of the Belt and Road Initiative. Also, the contribution of this initiative to the world is reaffirmed with phrases as "common development and prosperity", "global cooperation" and "win-win results". However, American side uses "smokescreen", "persuade", "pull", "lavish", "dominance", "China's hand" and other explicit negative vocabulary to describe the Belt and Road Initiative, trying to manipulate the public opinions to believe that it is China's ambition to dominate the world hiding behind this initiative. Clearly, the Chinese and American media have opposite attitudes toward the Belt and Road Initiative due to different political purposes of both parties, which is consistent with previous findings (Callahan, 2016).

\subsection{Concordance Plots of Words Related to American Media's Attitudes}

The attitudes of American media to the Belt and Road Initiative can be seen as a mixture of both doubts and positive changes. In particular, "power" and "control" show a trend of intensification over time. After further analysis, it is found that the first intensive area appears in May and June. It is because at that time, China held "The Belt and Road Forum for International Cooperation", with a view to make a joint plan with more than 130 participating countries for further cooperation and common development. The enthusiasm of the international community for supporting and participating in this initiative grew due to this forum, and more and more consensuses were reached during this forum. The American media are highly concerned about this. Therefore, there appears a noticeable increase in reports about China's using of this initiative to increase its global "power" and replace the dominance of America. At the same time, "cooperation" and "open" have also increased in American media's reports, which actually reflects the Trump administration's deepening understanding of this initiative. The Trump government no longer limits its focus to the threat that the initiative may bring to America, but to shed more light on its positive influence in promoting cooperation among countries and building an open economic development model, which has been pointed out by preceding research (Chen, Zhang, Wei, \& Hu, 2019; Fallon, 2015).

\section{Conclusion}

This study applies the CDA method to explore the meaning construction of the Belt and Road Initiative based on the corpus of China Daily and The New York Times, which are drawn from "Lexis Advance". By comparing and analyzing the high-frequency words, the collocation networks, the concordance lines and the concordance plots of words related to American media's attitudes in the two self-built corpora, this study interprets the attitudes of the two countries' media towards the Belt and Road Initiative and the political intentions behind it. Major findings are as follows: First, both the Chinese and American media have acknowledged that the Belt and Road Initiative involves many countries and brings opportunities for the development of the world economy. Second, the Chinese and American media have different focuses on the content of the reports. Chinese media focus on the specific measures of the initiative, while the American media on its political influence. Third, the Chinese and American media have significant differences in their reporting attitudes. The Chinese side tends to use explicit positive vocabulary to appraise the contribution of the initiative, while side uses explicit negative vocabulary to reflect the American government's doubts and concerns about the initiative. Fourth, since Trump took office, the American government has gradually changed its attitudes towards the initiative. Although there are still many negative comments, the positive voice has gradually increased. To summarize, this study deepens readers' understanding of the Belt and Road Initiative in the eyes of domestic and foreign media, and provides an empirical basis for the effective dissemination of domestic news reports. It is meaningful for the domestic media to better respond to the public opinions of other countries, enhance mutual trust and reciprocity between the two governments with the help of the media, and thus enhance China's discourse power in the international community. However, Chinese media's reports concerning this initiative outnumber that of American media and the coverage of most reports in China Daily have dedicated longer pages to the intricacies of this initiative than The New York Times. Therefore, the number of words contained is different in size in the two self-built corpora. The lack of accessibility to every Chinese and American media might also be an explanation for this incomparability of the two corpora. Based on the exploratory research characteristics of this study, it is suggested that the relevant research in the later stage can lengthen the time of diachronic research, expand the scope of the 
corpus, and use various scientific analysis tools to continuously improve such research.

\section{Acknowledgments}

The authors gratefully acknowledge the research project supported by the Central Universities Foundation of Zhejiang University.

\section{References}

Baker, P., Gabrielatos, C., KhosraviNik, M., Krzyżanowski, M., McEnery, T., \& Wodak, R. (2008). A useful methodological synergy? Combining critical discourse analysis and corpus linguistics to examine discourses of refugees and asylum seekers in the UK press. Discourse \& Society, 19(3), 273-306. https://doi.org/10.1177/0957926508088962

Blanchard, J. F., \& Flint, C. (2017). The geopolitics of China's maritime silk road initiative. Geopolitics, 2(22). 223-245. https://doi.org/10.1080/14650045.2017.1291503

Callahan, W. A. (2016). China's “Asia dream": The Belt Road Initiative and the new regional order. Asian Journal of Comparative Politics, 1(3), 226-243. https://doi.org/10.1177/2057891116647806

Chen, J., \& Hu, J. (2018). Enhancing L2 learners' critical thinking skills through a connectivism-based intelligent learning system. International Journal of English Linguistics, 8(6), 12-21. https://doi.org/10.5539/ijel.v8n6p12

Chen, J., Zhang, Y., Wei, Y., \& Hu, J. (2019). Discrimination of the contextual features of top performers in scientific literacy using a machine learning approach. Research in Science Education, March. https://doi.org/10.1007/s11165-019-9835-y

Du, J., \& Zhang, Y. (2018). Does one belt one road initiative promote Chinese overseas direct investment? China Economic Review, 47, 189-205. https://doi.org/10.1016/j.chieco.2017.05.010

Fairclough, N. (1992). Discourse and social change. Cambridge, UK: Polity.

Fairclough, N. (1995). Critical discourse analysis: The critical study of language. London, UK: Longman.

Fallon, T. (2015). The new silk road: Xi Jinping's grand strategy for Eurasia. American Foreign Policy Interests, 37(3), 140-147. https://doi.org/10.1080/10803920.2015.1056682

Han, L., Han, B., Shi, X., Su, B., Lv, X., \& Lei, X. (2018). Energy efficiency convergence across countries in the context of China's belt and road initiative. Applied Energy, 213, 112-122. https://doi.org/10.1016/j.apenergy.2018.01.030

Hao, Y., Lu, B., \& Guy, S. (2018). Economic and cultural implications of China's one belt one road initiative for the film industry: Cultural distance and taste preference. Australian Economic Papers, 57(3), 250-264. https://doi.org/10.1111/1467-8454.12116

Hong, Y. (2016). Motivation behind China's "One Belt, One Road" initiatives and establishment of the Asian Infrastructure Investment Bank. Journal of Contemporary China, 26(105), 353-368. https://doi.org/10.1080/10670564.2016.1245894

Hou, J., Chen, S., \& Xiao, D. (2018). Measuring the benefits of the "One belt, One road" initiative for manufacturing industries in China. Sustainability, 10(12), 1-16. https://doi.org/10.3390/su10124717

Hu, J., \& Wei, Y. (2018). The centrality of creativity: A new perspective on English language teaching. English Today, 35(2), 60-62. https://doi.org/10.1017/S0266078418000299

Li, C. J. (2015). Beidou system backs the "Belt and Road" Initiative. Aerospace China, 16(2), 2-4.

Li, D. J. (2015). Regional studies and the cultural rise strategy of the "One Belt and One road" developmental concept. Academics, 63(8), 262-266. https://doi.org/10.3969/j.issn.1002-1698.2015.08.028

Liu, H. F., Tian, D. K., \& Liu, Y. (2018). The Belt and Road Initiative and reconstruction of the world order: Strategic reflections basing on a China-led New Era. The Journal of Applied Business and Economics, 20(5), $46-60$.

Muhammad, A., \& Ling, Y. B. (2018). Belt and Road Initiative: A spirit of Chinese cultural thought. International Journal of Business and Management, 13(12), 9-16. https://doi.org/10.5539/ijbm.v13n12p9

Northey, M., \& Mckibbin, J. (1999). Discourse in late modernity. Encyclopedia of Sciences \& Religions, 20(4), 487-493.

Peter, F. (2016). Westward ho-the China dream and 'one belt, one road': Chinese foreign policy under Xi 
Jinping. International Affairs, 92(4), 941-957. https://doi.org/10.1111/1468-2346.12660

Summers, T. (2016). China's "New Silk Roads": Sub-national regions and networks of global political economy. Third World Quarterly, 37(9), 1628-1643. https://doi.org/10.1080/01436597.2016.1153415

Wei, Y., Yang, Q., Chen, J., \& Hu, J. (2018). The exploration of a machine learning approach for the assessment of learning styles changes. Mechatronic Systems and Control, 46(3), 121-126. https://doi.org/10.2316/Journal.201.2018.3.201-2979

Yan, Li. (2018). Study on China's languages' status planning for “The Belt and Road Initiative": Proposing the ecology-of-language paradigm. Theory and Practice in Language Studies, 8(5), 492-497. https://doi.org/10.17507/tpls.0805.05

Yang, Y., Shen, Z., Wu, Z., Luo, L., Liu, J., \& Liu, B. (2017). Strategy programming for acupuncture development along One-Belt-One-Road countries. Chinese Acupuncture \& Moxibustion, 37(4), 343-348. https://doi.org/10.13703/j.0255-2930.2017.04.001

Zhang, Y., Jin, Y., \& Shen, B. (2018). Measuring the energy saving and $\mathrm{CO}_{2}$ emissions reduction potential under China's Belt and Road Initiative. Computational Economics, 1-22. https://doi.org/10.1007/s10614-018-9839-0

Zhao, M. H. (2016). The belt and road initiative and its implications for China-Europe relations. International Spectator, 51(4), 1-10. https://doi.org/10.1080/03932729.2016.1235819

\section{Copyrights}

Copyright for this article is retained by the author, with first publication rights granted to the journal.

This is an open-access article distributed under the terms and conditions of the Creative Commons Attribution license (http://creativecommons.org/licenses/by/4.0/). 